\title{
High $\mathrm{CO}_{2}$ and Silicate Limitation Synergistically Increase the Toxicity of Pseudo-nitzschia fraudulenta
}

\author{
Avery O. Tatters, Fei-Xue Fu, David A. Hutchins* \\ Department of Biological Sciences, University of Southern California, Los Angeles, California, United States of America
}

\begin{abstract}
Anthropogenic $\mathrm{CO}_{2}$ is progressively acidifying the ocean, but the responses of harmful algal bloom species that produce toxins that can bioaccumulate remain virtually unknown. The neurotoxin domoic acid is produced by the globallydistributed diatom genus Pseudo-nitzschia. This toxin is responsible for amnesic shellfish poisoning, which can result in illness or death in humans and regularly causes mass mortalities of marine mammals and birds. Domoic acid production by Pseudo-nitzschia cells is known to be regulated by nutrient availability, but potential interactions with increasing seawater $\mathrm{CO}_{2}$ concentrations are poorly understood. Here we present experiments measuring domoic acid production by acclimatized cultures of Pseudo-nitzschia fraudulenta that demonstrate a strong synergism between projected future $\mathrm{CO}_{2}$ levels $(765 \mathrm{ppm})$ and silicate-limited growth, which greatly increases cellular toxicity relative to growth under modern atmospheric $(360 \mathrm{ppm})$ or pre-industrial $(200 \mathrm{ppm}) \mathrm{CO}_{2}$ conditions. Cellular Si:C ratios decrease with increasing $\mathrm{CO}_{2}$, in a trend opposite to that seen for domoic acid production. The coastal California upwelling system where this species was isolated currently exhibits rapidly increasing levels of anthropogenic acidification, as well as widespread episodic silicate limitation of diatom growth. Our results suggest that the current ecosystem and human health impacts of toxic Pseudonitzschia blooms could be greatly exacerbated by future ocean acidification and 'carbon fertilization' of the coastal ocean.
\end{abstract}

Citation: Tatters AO, Fu F-X, Hutchins DA (2012) High $\mathrm{CO}_{2}$ and Silicate Limitation Synergistically Increase the Toxicity of Pseudo-nitzschia fraudulenta. PLoS ONE 7(2): e32116. doi:10.1371/journal.pone.0032116

Editor: Brett Neilan, University of New South Wales, Australia

Received December 9, 2011; Accepted January 23, 2012; Published February 21, 2012

Copyright: (c) 2012 Tatters et al. This is an open-access article distributed under the terms of the Creative Commons Attribution License, which permits unrestricted use, distribution, and reproduction in any medium, provided the original author and source are credited.

Funding: This study was fully supported by the United States National Science Foundation (NSF) grants OCE 0850730, 0942379, and 0962309. NSF URL: http:// www.nsf.gov/. The funders had no role in study design, data collection and analysis, decision to publish, or preparation of the manuscript.

Competing Interests: The authors have declared that no competing interests exist.

*E-mail: dahutch@usc.edu

\section{Introduction}

The relentless consumption of fossil fuels is forcing carbon dioxide $\left(\mathrm{CO}_{2}\right)$ into the oceans at the rate of $\sim 20-25$ million tons day $^{-1}$, driving a steady decrease in seawater $\mathrm{pH}$ often termed ocean acidification [1,2]. Marine phytoplankton can be sensitive to the rising partial pressure of $\mathrm{CO}_{2}\left(\mathrm{pCO}_{2}\right)$ and lowered $\mathrm{pH}$, as well as other concurrent environmental changes such as decreases in nutrient supplies to surface waters due to enhanced stratification [3]. Only of late, however, have oceanographers begun to examine how these ocean global change trends will affect the phytoplankton species that cause ecosystem-damaging toxic algal blooms [4]. Recent documented global increases in the frequency and severity of harmful algal blooms are hypothesized to be linked to changing anthropogenic atmospheric emissions and nutrient supplies, but direct causal evidence is lacking [5]. In particular, the possible synergistic effects of multiple climate change variables remain largely unexplored [3].

Among the most widely distributed and environmentally destructive harmful bloom species are diatoms of the genus Pseudo-nitzschia [6]. Many Pseudo-nitzschia species produce the potent toxin domoic acid, which binds with high affinity to vertebrate kainite-type ionotropic glutamate neuroreceptors [7]. Domoic acid is the agent of Amnesic Shellfish Poisoning, which causes illness or mortality in humans, marine mammals, and seabirds that ingest fish or shellfish that have been contaminated through bioaccumulation in coastal food webs $[8,9]$. Previous studies have highlighted multiple triggers for increased domoic acid production, including nutrient limitation, extreme $\mathrm{pH}$ increases, trace metal availability and nitrogen source changes [10-16]. Recently Sun et al., (2011) notably demonstrated that culture toxicity increased substantially when phosphorous-limitation is combined with higher $\mathrm{pCO}_{2}$ in a Pseudo-nitzschia multiseries clone from Nova Scotia, Canada [17].

Extremely elevated levels of domoic acid have recently been reported from Pseudo-nitzschia blooms in coastal waters of Southern California [18]. One of the common species within these mixed blooms is $P$. fraudulenta. Our study examined how the availability of the required diatom nutrient silicate $\left(\mathrm{Si}(\mathrm{OH})_{4}\right)$ interacts with changing $\mathrm{pH}$ and $\mathrm{pCO}_{2}$ (8.4 and 200 ppm pre-industrial; 8.2 and 360 ppm modern day; and 7.9 and 765 ppm, projected year 2100) to influence toxicity, growth, and silicon utilization in a $P$. fraudulenta clone isolated from Southern California waters.

\section{Results and Discussion}

We found that the concentration of domoic acid in $P$. fraudulenta cells increases significantly under $\mathrm{Si}(\mathrm{OH})_{4}$ limitation, as has been reported in prior studies for other Pseudo-nitzschia species $[10,11,19,20]$. Our results demonstrate, however, that this previously recognized $\mathrm{Si}(\mathrm{OH})_{4}$ effect on cellular toxin production rates is dramatically magnified $(>250 \%)$ during growth at projected end-of-century atmospheric $\mathrm{pCO}_{2}$ levels (765 ppm). Thus, these $\mathrm{Si}(\mathrm{OH})_{4}$-limited diatom cells produce more than twice as much toxin when grown in acidified seawater. This nutrient/ acidification synergism is environmentally relevant, as the 
California coast where this species was isolated is among the first ocean regimes where anthropogenically-acidified surface seawater has been documented during upwelling events [21]. Coincidentally, $\mathrm{Si}(\mathrm{OH})_{4}$ limitation of diatoms is also a common biogeochemical feature in parts of this regime [22].

This strong toxin production synergism between $\mathrm{Si}(\mathrm{OH})_{4}$ limitation of Pseudo-nitzschia fraudulenta and ocean acidification is shown in Fig. 1a. Relative to nutrient-replete cultures grown at the same $\mathrm{pH}$, the cellular domoic acid production rates $\left(\mathrm{pg}\right.$ cell $^{-1}$ day $^{-1}$ ) of $\mathrm{Si}(\mathrm{OH})_{4}$-limited diatom cells were elevated $\sim 4-7$ fold (Fig. 1a, $\mathrm{p}<0.0001$ ). Within these $\mathrm{Si}(\mathrm{OH})_{4}$-limited treatments, cellular domoic acid production rates were highest in cultures acclimated at projected year 2100 seawater $\mathrm{pH}(\sim 7.9)$. Toxin production rates within this acidified treatment were increased $\sim 4.2$-fold compared to cells maintained at pre-industrial $\mathrm{pH}$ $(\sim 8.4, \mathrm{p}=0.001)$, and 2.5 -fold relative to those maintained at modern $\mathrm{pH}$ levels of $\sim 8.2$ (Fig. la, $\mathrm{p}=0.004$ ). There was a highly significant negative linear correlation between domoic acid production rates and $\mathrm{pH}$ in these $\mathrm{Si}(\mathrm{OH})_{4}$-limited cultures $\left(r^{2}=0.94\right)$. Toxin production rates of nutrient-replete cells were substantially reduced, but also increased significantly $(\mathrm{p}<0.01)$ in a linear manner $\left(\mathrm{r}^{2}=1.0\right)$ with successive decreases in $\mathrm{pH}$ (Fig. 1a, inset).

Similar to cellular production rates, cellular domoic acid quotas (total cellular toxin content, pg cell ${ }^{-1}$ ) were $7-18$-fold higher in $\mathrm{Si}(\mathrm{OH})_{4}$-limited cultures relative to nutrient-replete cultures (Fig. 1b, p $<0.0001)$. Domoic acid quotas in these $\mathrm{Si}(\mathrm{OH})_{4}$-limited treatments were 3-fold higher at $\mathrm{pH} 7.9$ than at $\mathrm{pH} 8.4$ $(\mathrm{p}=0.0003)$, and increased 1.4 -fold at $\mathrm{pH} 7.9$ relative to $\mathrm{pH} 8.2$ $(\mathrm{p}=0.002)$. The inverse relationship between toxin quotas and $\mathrm{pH}$ under $\mathrm{Si}(\mathrm{OH})_{4}$-limitation was again highly linear $\left(\mathrm{r}^{2}=0.94\right)$ across the three $\mathrm{pH}$ levels. Due to the inherent chemical relationships of the seawater carbonate buffer system, in the $\mathrm{Si}(\mathrm{OH})_{4}$-limited treatments cellular domoic acid quotas (and production rates, not shown) were also strongly positively correlated with $\mathrm{pCO}_{2}$ $\left(r^{2}=0.99\right.$, Fig. 1c). The much lower domoic acid content of nutrient-replete cells also increased at lower $\mathrm{pH}$ and higher $\mathrm{pCO}_{2}$, but these toxin quota changes were not significant (panel insets, Fig. 1b,c, $\mathrm{p}>0.05)$.

As intended in our experimental design, specific growth rates of $\mathrm{Si}(\mathrm{OH})_{4}$-limited $P$. fraudulenta cultures were significantly reduced compared to nutrient-replete cells in all three $\mathrm{pCO}_{2}$ treatments $(\mathrm{p}<0.01$, Fig. 2a). In the nutrient-replete cultures, there were significant progressive increases in growth rates across all three $\mathrm{pCO}_{2}$ levels, with increases of $48 \%$ and $66 \%$ relative to the $200 \mathrm{ppm}$ treatment at 360 and 765 ppm, respectively $(\mathrm{p}<0.0009)$. $\mathrm{Si}(\mathrm{OH})_{4}$-limited culture growth rates also increased significantly with $\mathrm{pCO}_{2}$, but to a lesser degree $(\mathrm{p}<0.03$, Fig. 2a, inset). These trends were confirmed in the semi-continuous cultures by steadystate concentrations of particulate organic carbon and nitrogen, proxies for total diatom biomass in the treatments (Fig. 3a,b).

The relationship between growth rate and cellular domoic acid quota was bimodal. Elevated domoic acid levels were only produced by cultures below a specific growth rate threshold of $\sim 0.15 \mathrm{~d}^{-1}$; at all higher growth rates in the nutrient-replete cultures, cellular toxin quotas were low, and there was no evident relationship between growth rate and cellular toxin content across the data set as a whole (Fig. 2b). However, due to the stimulatory effect of $\mathrm{CO}_{2}$ on both growth and toxicity, cellular domoic acid quotas were positively linearly correlated with growth rates within each nutrient treatment $\left(\mathrm{Si}(\mathrm{OH})_{4}\right.$-limited, $\mathrm{r}^{2}=0.99$; nutrientreplete, $r^{2}=0.96$, Fig. $2 b$ and inset).

The trends we observed in toxin levels could be due in part to changes in individual cell mass or biovolume under our
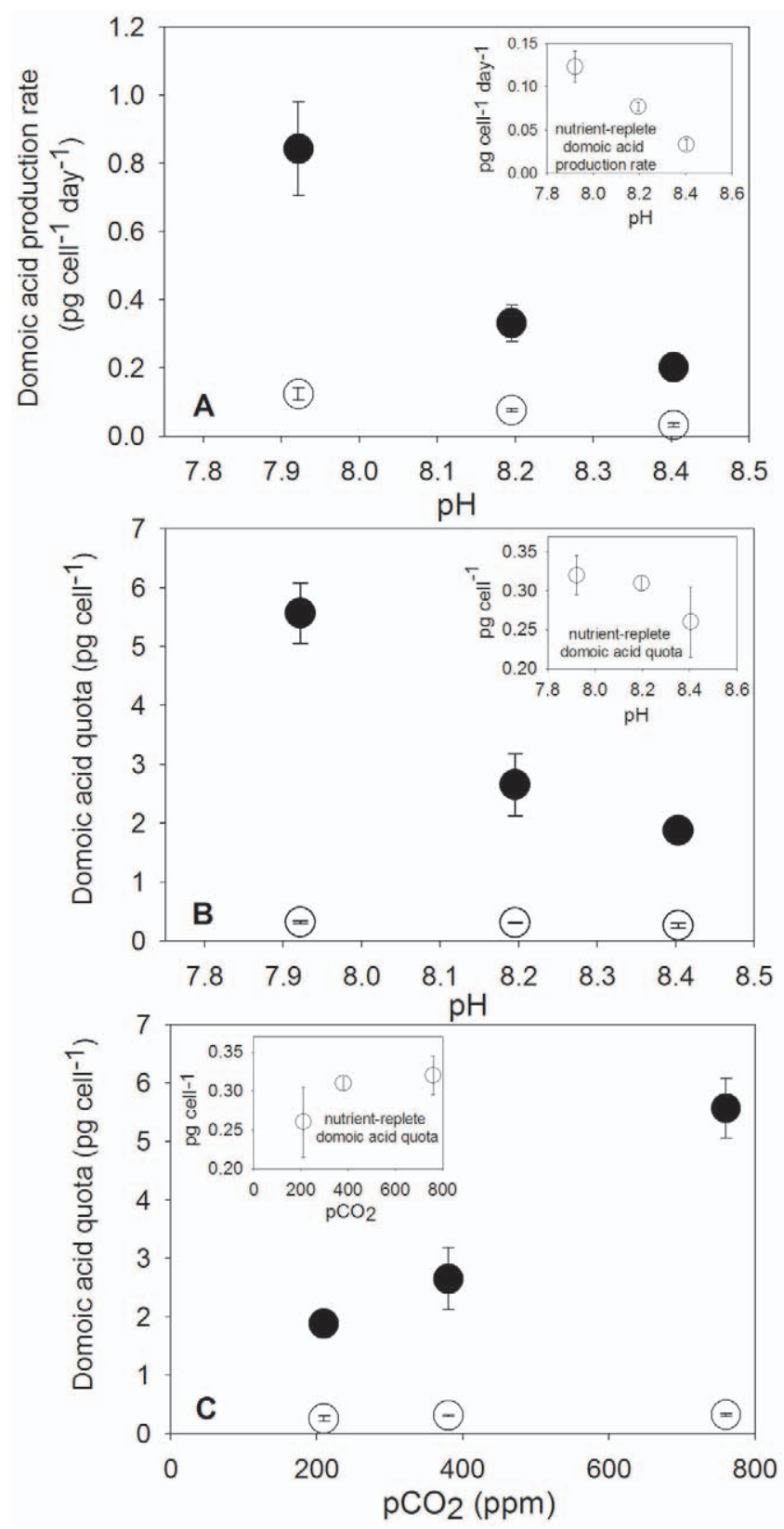

Figure 1. Interactive effects of $\mathrm{pH}$ and $\mathrm{pCO}_{2}$ with nutrient limitation control Pseudo-nitzschia fraudulenta toxicity. Cellular domoic acid production rates (pg cell ${ }^{-1}$ day $^{-1}$ ) versus $\mathrm{pH}$ (a) and domoic acid quotas (pg cell ${ }^{-1}$ ) versus $\mathrm{pH}(\mathbf{b})$ and $\mathrm{pCO}_{2}$ (c) in Pseudonitzschia fraudulenta cultures grown under $\mathrm{Si}(\mathrm{OH})_{4}$-limited $(\mathbf{O})$ and nutrient-replete $(O)$ conditions at seawater $\mathrm{CO}_{2}$ concentrations of $200 \mathrm{ppm}$ (preindustrial atmospheric levels), $360 \mathrm{ppm}$ (modern levels), and $765 \mathrm{ppm}$ (projected year 2100 levels). Panel insets present the nutrient-replete data with an expanded Y-axis scale for clarity. Error bars represent standard deviations of triplicates for each treatment. doi:10.1371/journal.pone.0032116.g001

experimental treatments. Measurements of particulate organic carbon and nitrogen cell quotas $\left(\mathrm{mol} \mathrm{cell}^{-1}\right)$ suggested a 1.5 to 2fold increase in cell size in all $\mathrm{Si}(\mathrm{OH})_{4}$-limited cultures relative to nutrient-replete treatments grown at the same $\mathrm{pCO}_{2}$ levels (Fig. 3c,d, p <0.0001), a not-uncommonly observed phenomenon in slowly growing, $\mathrm{Si}(\mathrm{OH})_{4}$-limited diatoms. Cell mass also increased slightly but not significantly with $\mathrm{pCO}_{2}$ (Fig. 3c,d, 

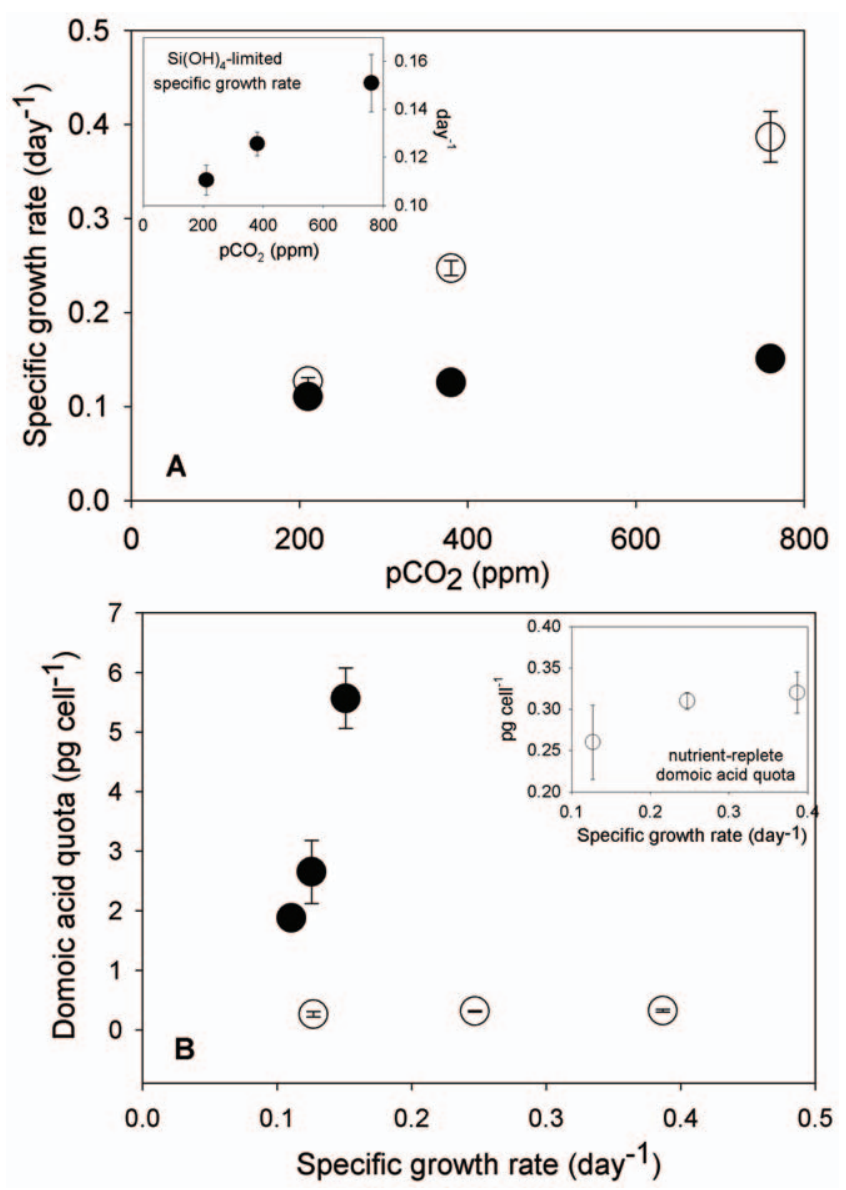

Figure 2. Relationships between nutrient-limited growth rates, $\mathbf{p C O}_{2}$, and toxicity in Pseudo-nitzschia fraudulenta. Specific growth rates $\left(\right.$ day $^{-1}$ ) versus $\mathrm{pCO}_{2}$ (a) and cellular domoic acid quota ( $\mathrm{pg}$ cell ${ }^{-1}$ ) versus specific growth rates $(\mathbf{b})$ under $\mathrm{Si}(\mathrm{OH})_{4}$-limited $(\mathbf{O})$ and nutrientreplete $(\bigcirc)$ conditions at three seawater $\mathrm{CO}_{2}$ concentrations $(200,360$ and $765 \mathrm{ppm})$. Panel insets present the $\mathrm{Si}(\mathrm{OH})_{4}$-limited (a) or nutrientreplete (b) data with an expanded Y-axis scale for clarity. Error bars represent standard deviations of triplicates for each treatment. doi:10.1371/journal.pone.0032116.g002

$\mathrm{p}>0.05)$. Thus the higher cell-normalized toxin levels in $\mathrm{Si}(\mathrm{OH})_{4^{-}}$ limited, high $\mathrm{CO}_{2}$-grown cells could be partially related to increases in the size and volume of individual P. fraudulenta cells. However, the observed increases in cellular toxin quotas in our experimental $\mathrm{Si}(\mathrm{OH})_{4}$-limited treatments (7-18-fold) were up to an order of magnitude greater than the corresponding increases in cell mass suggested by the data in Fig. 3c,d, so both nutrient limitation and ocean acidification appear to have physiological consequences resulting in large increases in toxin production per unit of diatom biomass.

Cellular biogenic silica to particulate organic carbon $(\mathrm{Si}: \mathrm{C})$ ratios were significantly lower at 765 than at $200 \mathrm{ppm}$ ppm $\mathrm{CO}_{2}$ in both $\mathrm{Si}(\mathrm{OH})_{4}$ treatments $(\mathrm{p}<0.05)$, although neither was significantly different from Si:C ratios at $360 \mathrm{ppm}(\mathrm{p}>0.05$, Fig. 4a). These data are corroborated by the findings of Sun et al., (2011) in a $P$. multiseries clone grown at a similar range of $\mathrm{pCO}_{2}$ [17]. Milligan et al., (2004) observed lower Si cell quotas (mol Si cell $^{-1}$ ) under more acidic conditions in cultures of the centric diatom Thalassiosira weissflogii due to higher cellular Si efflux:influx ratios [23]. However, unlike the results of Milligan et al., cellular $\mathrm{Si}$ quotas in our $P$. fraudulenta isolate did not differ significantly between $\mathrm{CO}_{2}$ treatments (data not shown), and the $\mathrm{Si}$ C trends we observed were instead due entirely to increasing cellular particulate organic carbon quotas at higher $\mathrm{CO}_{2}$ concentrations (Fig. 3c). It is notable that in our pennate diatom, Si:C increases at low $\mathrm{CO}_{2}$ occurred even in $\mathrm{Si}(\mathrm{OH})_{4}$-limited cultures (Fig. $4 \mathrm{a}$ ).

Cellular Si:C ratios were negatively linearly related to culture growth rates in both $\mathrm{Si}(\mathrm{OH})_{4}$-limited $\left(\mathrm{r}^{2}=0.99\right)$ and $\mathrm{Si}(\mathrm{OH})_{4}$ replete $\left(r^{2}=0.77\right)$ cultures (Fig. $\left.4 b\right)$. This observation that Si:C ratios are highest in diatoms under $\mathrm{CO}_{2}$-limited growth conditions (Fig. 4b) is similar to the Si:C increases typically seen in diatoms growing under iron limitation [22,24]. The inverse trends in cellular $\mathrm{Si}: \mathrm{C}$ ratios relative to $\mathrm{CO}_{2}$ levels and growth rates are however the opposite of the positive linear correlations we observed for toxin production rates and quotas versus these same two variables (Figs. 1c, 2b).

The synergism between elevated $\mathrm{pCO}_{2}$ and nutrient limitation in a widespread Pseudo-nitzschia species suggests that ocean acidification or 'carbon fertilization' could dramatically amplify the already considerable worldwide ecosystem impacts of toxic blooms, especially under commonly occurring nutrient-limited conditions. The west coast of North America where we isolated this clone is the first region where upwelling of anthropogenicallyacidified seawater has been unambiguously demonstrated [21]. This same coastline is also plagued by large, frequently recurring toxic Pseudo-nitzschia blooms [18,25,26]. When fossil fuel-derived ocean acidification combines with naturally elevated $\mathrm{pCO}_{2}$ from upwelled deeper waters, surface water $\mathrm{pH}$ values here can be as low as 7.6 and $\mathrm{pCO}_{2}$ levels can reach 1000-1200 ppm [21]. By comparison, $\mathrm{pH}$ values of $\sim 7.9$ and $\mathrm{pCO}_{2}$ of $765 \mathrm{ppm}$ more than doubled diatom toxin production rates in our cultures, relative to modern atmospheric $\mathrm{pCO}_{2}$ levels (Fig. 1a).

In our experiments, $\mathrm{CO}_{2}$-driven increases in toxin production were much more evident in cultures limited by $\mathrm{Si}(\mathrm{OH})_{4}$ than in nutrient-replete treatments. Regulation of domoic acid production has been previously linked to $\mathrm{Si}(\mathrm{OH})_{4}$ limitation in several other Pseudo-nitzschia species [10,11,19,20]. Inverse correlations between $\mathrm{Si}(\mathrm{OH})_{4}$ levels and domoic acid concentrations have been demonstrated during Pseudo-nitzschia blooms in southern California waters, and modeling approaches have suggested a role for $\mathrm{Si}(\mathrm{OH})_{4}$ limitation in determining domoic acid toxicity throughout much of central and southern California [18,27,28]. Chronic iron limitation of diatoms in some California upwelling centers also leads to ecosystem-level $\mathrm{Si}(\mathrm{OH})_{4}$-limitation, since iron-stressed cells produce heavier silica frustules and so deplete $\mathrm{Si}(\mathrm{OH})_{4}$ from surface waters long before other nutrients [22,24].

The combination of high $\mathrm{pCO}_{2}$, acidified water with frequent and widespread $\mathrm{Si}(\mathrm{OH})_{4}$ limitation of toxic Pseudo-nitzschia assemblages could have major consequences for marine environmental health in the California region, and in other areas where similar conditions exist. Indeed, an environmental survey data set from the northern Gulf of Mexico shows correlations between low $\mathrm{Si}(\mathrm{OH})_{4}$ availability, elevated dissolved inorganic carbon concentrations, and increased toxin levels in Pseudo-nitzschia cells [29]. Our study is also validated by the findings of Sun et al., (2011), who found elevated domoic acid levels in another species (P. multiseries) cultured under phosphorous-limited, low $\mathrm{pH}$ (high $\mathrm{pCO}_{2}$ ) conditions [17]. However, our results may have considerably broader environmental implications since previous studies suggest that $\mathrm{Si}(\mathrm{OH})_{4}$-limitation of Pseudo-nitzschia growth is likely to be much more common and widespread than phosphorous-limitation $[18,27,28]$.

In addition to increased toxicity, increasing $\mathrm{pCO}_{2}$ resulted in significantly higher specific growth rates for both nutrient-replete and $\mathrm{Si}(\mathrm{OH})_{4}$-limited cells (Fig. 2a), as well as increased carbon fixation rates (data not shown). Thus, ocean acidification could not 

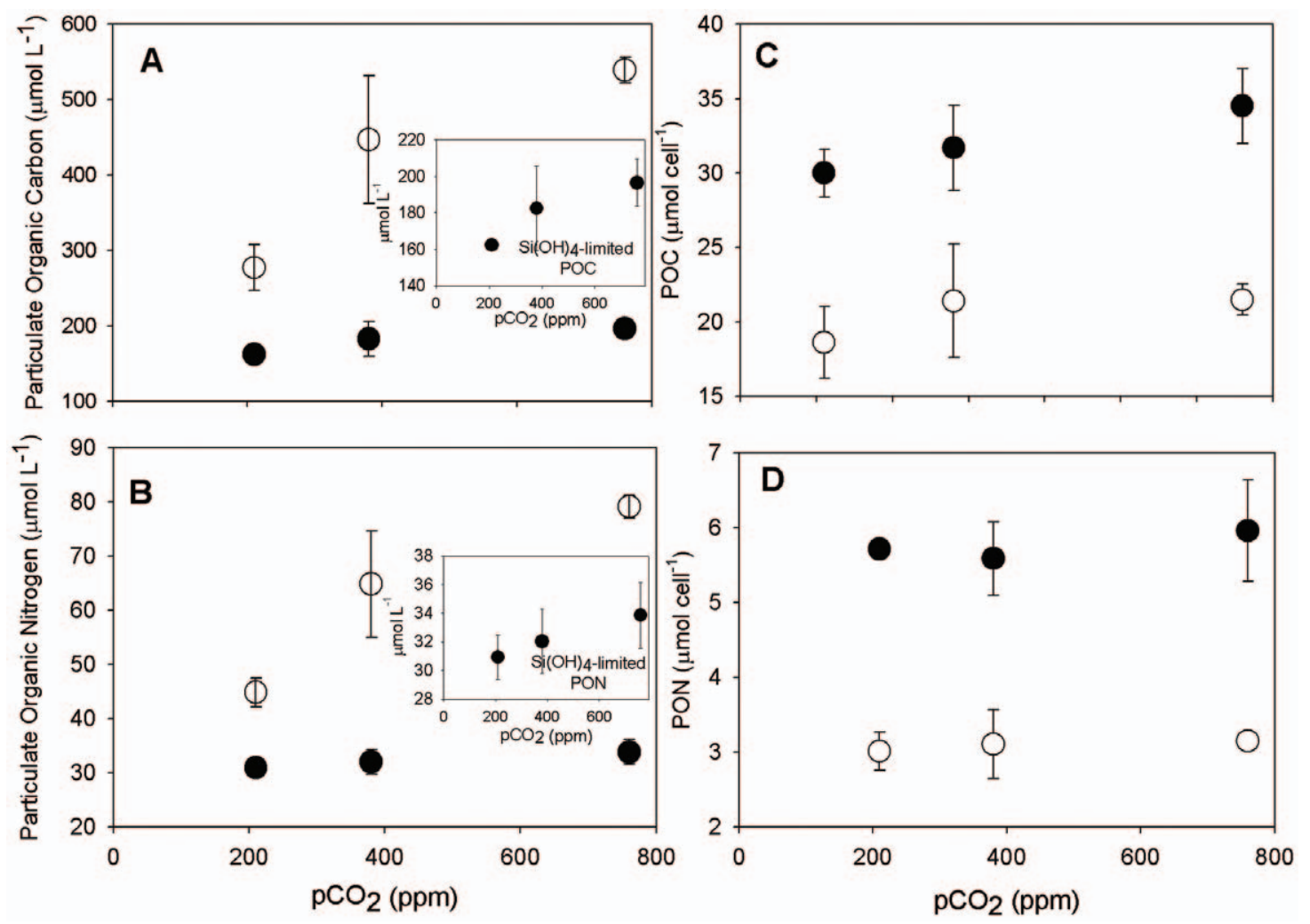

Figure 3. Steady-state particulate organic carbon (POC) (a) and nitrogen (PON) (b) concentrations $\left(\mu \mathrm{mol}^{-1}\right)$, particulate organic carbon (POC) (c) and nitrogen (PON) (d) cell quotas (mol cell ${ }^{-1}$ ) in semi-continuous Pseudo-nitzschia fraudulenta cultures grown

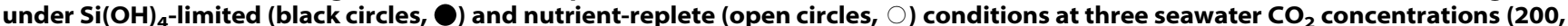
360 and $765 \mathrm{ppm})$. Panel insets present the $\mathrm{Si}(\mathrm{OH})_{4}$-limited data with an expanded $\mathrm{Y}$-axis scale for clarity. Error bars represent standard deviations of triplicates for each treatment.

doi:10.1371/journal.pone.0032116.g003

only enhance the toxicity of Pseudo-nitzschia blooms, but may also increase growth rates and biomass, even under $\mathrm{Si}(\mathrm{OH})_{4}$-limited conditions when cellular domoic acid production is elevated.

The physiological and genetic mechanisms underlying this $\mathrm{CO}_{2}$-nutrient limitation toxicity synergism are undetermined at present, but may have to await elucidation of the full biosynthetic pathway of domoic acid. Complete synthesis results from condensation of an alpha-ketoglutarate derivative stemming from the tricarboxylic acid cycle with a C-10 isoprenoid unit likely originating from an unknown compartmentalized pathway within the cell. As this latter component of the synthetic pathway is poorly understood [30], our ability to obtain a truly mechanistic picture of how domoic acid production is regulated by environmental variables is limited. Application of modern transcriptomic and proteomic methods to toxic Pseudo-nitzschia cultures of varying potencies is likely to be productive in this regard; the ability to quantitatively and sensitively up- and down-regulate cellular domoic acid levels by manipulating the nutrient conditions and $\mathrm{pCO}_{2}$ at which cultures are grown may prove invaluable for such mechanistic molecular studies. Future work also needs to examine how the interactions between rising $\mathrm{pCO}_{2}$ and other global change trends such as warming temperatures and increased irradiance in shallower ocean mixed layers [3,4] will affect Pseudo-nitzschia growth and toxicity. In particular, increasing $\mathrm{pCO}_{2}$ combined with iron limitation, which was also demonstrated to regulate domoic acid production [14,15,31], should be considered in future studies, as well as co-limitation by multiple factors including iron, light, silicate, and nitrate [32].
The implications of our results are not limited to the distant future. In fact, the range of $\mathrm{pCO}_{2}$ levels found in anthropogenically-acidified waters of the California upwelling regime today already encompasses those used in our study, including projected average year 2100 atmospheric concentrations [21]. Thus, Pseudonitzschia bloom toxicity may already be affected by changing $\mathrm{pCO}_{2}$ levels here, and this area may be considered a natural laboratory in which to evaluate the effects of future global ocean acidification on harmful algal blooms. Strong synergistic effects of rising $\mathrm{pCO}_{2}$ with other variables such as nutrient limitation emphasize the need for heightened future vigilance by marine environmental regulatory and protection agencies, as well as a possible need to add new parameters such as seawater carbonate system measurements to existing harmful algal bloom detection and monitoring efforts. Such unprecedented measures may well be necessary to help mitigate escalating environmental and economic damage from increasingly toxic Pseudo-nitzschia blooms in a rapidly acidifying ocean.

\section{Materials and Methods}

\section{Culture, Media, and Sampling}

Pseudo-nitzschia fraudulenta was micropipette isolated from public nearshore water collected at $34.08 \mathrm{~N}, 119.05 \mathrm{~W}$ in Ventura County, California in March, 2010. This isolate, designated USC WWA7, was maintained at $16^{\circ} \mathrm{C}$ on a 12-h light: 12-h dark cycle in modified $\mathrm{f} / 2$ enriched seawater growth media [33] under 90 photons $\mathrm{m}^{-2} \mathrm{~s}^{-1}$ of cool white fluorescent illumination. Silicate 



Figure 4. Relationships between cellular Si:C ratios, $\mathrm{pCO}_{2}$, and growth rates in Pseudo-nitzschia fraudulenta. Cellular silica to particulate organic carbon (Si:C, mol:mol) ratios versus $\mathrm{pCO}_{2}(\mathbf{a})$ and cellular Si:C versus specific growth rates $(\mathbf{b})$ under $\mathrm{Si}(\mathrm{OH})_{4}$-limited (O) and nutrient-replete $(O)$ conditions at three seawater $\mathrm{CO}_{2}$ concentrations (200, 360 and 765 ppm). Error bars represent standard deviations of triplicates for each treatment.

doi:10.1371/journal.pone.0032116.g004

$\left(\mathrm{Si}(\mathrm{OH})_{4}\right)$ final concentrations in the medium were $10.6 \mu \mathrm{M}$ for the $\mathrm{Si}(\mathrm{OH})_{4}$-limited treatment and $106.1 \mu \mathrm{M}$ for the nutrientreplete treatment; these concentrations were chosen based on previous experience with cultures of Chaetoceros and Thalassiosira spp. Dissolved $\mathrm{CO}_{2}$ concentrations were controlled by gentle bubbling with commercially prepared air $/ \mathrm{CO}_{2}$ mixtures (Praxair Gas) at approximately 120 bubbles $\cdot \min ^{-1}$ with in-line HEPA filters to avoid particulate contamination.

\section{Cell Counts and Growth Rates}

Steady state semi-continuous culture methodology was employed to maintain cultures in exponential state and specific growth rates were calculated as described in Sun et al., (2011) [17]. Growth rate as determined by bi-weekly microscopic cell counts and in vivo fluorescence determined the dilution rate of each bottle. Cells of $P$. fraudulenta preserved in acidified Lugol's solution were vortexed and enumerated by direct counts using an Accu-Scope 3032 inverted microscope according to the Utermöhl method [34]. A minimum of 300 cells were counted to guarantee a $95 \%$ confidence interval with $+/-11.5 \%$ accuracy [35]. Cultures were acclimated for a period of three months to the respective experimental conditions prior to splitting into triplicates, which were then further acclimated for one month (5-17 cell divisions) prior to final sampling.

\section{Domoic acid by high performance liquid chromatography}

High performance liquid chromatography with ultraviolet detection (HPLC-UV) of domoic acid was performed using a SCL-10ADVP controlled system (Shimadzu). The UV detector was programmed for sample and reference wavelengths of 242 and $280 \mathrm{~nm}$ respectively and the system was operated by EZ START software version 7.4 SP1 (Shimadzu).

Cellular concentrations of domoic acid were determined according to Mafra et al., (2009) with slight modifications [36]. Culture subsamples of 10-20 ml were carefully measured and cells were collected by gentle filtration on $25 \mathrm{~mm}$ GF/F filters (Whatman). The filters were stored in the dark at $-20^{\circ} \mathrm{C}$. Filters were subsequently subject to sonication in $10 \%$ aqueous methanol for $2 \mathrm{~min}$. at $40 \mathrm{~W}$ in a water bath. The cell extracts were then clarified by centrifugation at $3000 \times g$ for $10 \mathrm{~min}$ at $4^{\circ} \mathrm{C}$. The pellet was discarded and the clarified extracts were transferred to $300 \mu \mathrm{l}$ polyspring inserts (National Scientific) placed inside clean $2.0 \mathrm{ml}$ Target $\mathrm{DP}^{\mathrm{TM}}$ vials (National Scientific). Prior to analysis, all samples were treated with $0.15 \%$ trifluoroacetic acid (TFA).

Briefly, the chromatographic separation was carried out on a reversed phase Luna C18 (2) column (3 $\mu \mathrm{m}, 2 \times 100 \mathrm{~mm}$, Phenomenex) at $25^{\circ} \mathrm{C}$ with a mobile phase system consisting of water with $0.1 \%$ TFA (A), and acetonitrile $(\mathrm{MeCN})$ with $0.1 \%$ TFA (B). The elution gradient began with a $10-35 \%$ B transition over $10 \mathrm{~min}$, then was held at $35 \% \mathrm{~B}$ until $15 \mathrm{~min}$, followed by a subsequent decrease to $10 \% \mathrm{~B}$ at $16 \mathrm{~min}$, and held at $10 \% \mathrm{~B}$. The flow rate was $0.2 \mathrm{ml} \mathrm{min}^{-1}$ and the injection volume 5-10 $\mu \mathrm{l}$. Quantification of domoic acid was determined using certified reference material CRM-domoic acid-e obtained from the National Resource Council, Canada at a range of concentrations.

Calibration curves of CRM-domoic acid-e were determined by linear regressions $\left(r^{2}\right.$ values $\left.\geq 0.99\right)$ for each sample treatment. Interpolation from the standard curves was used to calculate the amount of compound injected from the peak areas of each sample under the same experimental conditions. Domoic acid per cell concentrations were determined by the ratio of reconstituted volume $(300 \mu \mathrm{l})$ to the volume injected $(5-10 \mu \mathrm{l})$ and dividing by the total cell count in the original sample. Reported values represent means of the results $(n=3)$. Domoic acid production rates were calculated by multiplying the growth rate by toxin per cell.

\section{Carbonate Buffer System analysis}

Dissolved inorganic carbon analysis was performed using a CM5230 $\mathrm{CO}_{2}$ coulometer (UIC) [17]. Samples were transferred carefully without agitation into $25 \mathrm{ml}$ liquid scintillation vials fitted with Teflon (PFTE) coated caps, poisoned with $200 \mu \mathrm{l}$ of $5 \%$ $\mathrm{HgCl}_{2} \mathrm{l}^{-1}$, and stored at $4^{\circ} \mathrm{C}$ until analysis. $\mathrm{pH}$ was determined on freshly collected samples using a calibrated Orion 5-star plus $\mathrm{pH}$ meter using an NBS buffer system with three-point calibration. The $\mathrm{pCO}_{2}$ in the experimental media was calculated from these two parameters using $\mathrm{CO}_{2} \mathrm{SYS}$ software [37]. Measured NBS scale $\mathrm{pH}$ values averaged across all the replicates in the three treatments were 8.43, 8.23, and 7.95; measured total dissolved inorganic carbon concentrations were 1965, 2107, and $2249 \mu \mathrm{mol} \mathrm{kg}^{-1}$; and the corresponding calculated $\mathrm{pCO}_{2}$ values were 198, 357, and $764 \mathrm{ppm}$. For clarity, $\mathrm{pCO}_{2}$ treatments in the cultures are referred to in the text using rounded-off values of 
200 ppm, pre-industrial atmospheric levels; 360 ppm, modern atmospheric levels: and 765 ppm, projected year 2100 levels [38].

\section{Chlorophyll $a$}

For chlorophyll $a(\mathrm{Chl} a)$ measurements, samples were filtered in duplicate onto $25 \mathrm{~mm}$ GF/F filters. Five $\mathrm{ml}$ of $90 \%$ acetone was later added and each vial was allowed to extract overnight in the dark at $-20^{\circ} \mathrm{C}$. After twenty-four hours, Chl $a$ was determined using a Turner Designs 10-AU fluorometer [39].

\section{Particulate organic carbon and nitrogen}

For particulate organic carbon (POC) and nitrogen (PON), sample volumes of $20 \mathrm{ml}$ were collected onto pre-combusted $\left(450^{\circ} \mathrm{C}\right.$ for $\left.5 \mathrm{~h}\right) \mathrm{GF} / \mathrm{F}$ glass fiber filters, stored at $-20^{\circ} \mathrm{C}$, and dried at $55^{\circ} \mathrm{C}$ before analysis. Molar POC and PON content was analyzed using a 4010 Costech Elemental Combustion System calibrated with methionine and atropine as reference materials according to the methods in Hutchins et al., (1998) and Fu et al., (2007) $[40,41]$.

\section{Biogenic Silica}

Sample volumes of $20 \mathrm{ml}$ were collected onto $0.6 \mu \mathrm{M}$ polycarbonate filters, dried and stored at ambient temperature

\section{References}

1. Doney SC, Fabry VJ, Feely RA, Kleypas JA (2009) Ocean acidification: The other $\mathrm{CO}_{2}$ problem. Annual Rev Mar Sci 1: 169-192.

2. Dybas CL (2006) On a collision course: oceans plankton and climate change. BioScience 56(8): 642-646.

3. Boyd PW, Strzepzk R, Fu F, Hutchins DA (2010) Environmental control of open-ocean phytoplankton groups: Now and in the future. Limnol Oceanogr 55(3): 1353-1380.

4. Hutchins DA, Mulholland MR, Fu F (2009) Nutrient cycles and marine microbes in a $\mathrm{CO}_{2}$-enriched ocean. Oceanography 22: 128-145.

5. Hallegraeff G (2010) Ocean climate change, phytoplankton community responses and harmful algal blooms: A formidable predictive challenge. J Phycol 46(2): 220-225.

6. Hasle GR (2002) Are most of the domoic acid-producing species of the diatom genus Pseudo-nitzschia cosmopolites? Harmful Algae 1(2): 137-146.

7. Peng YG, Ramsdell JS (1996) Brain fos induction is a sensitive biomarker for the lowest observed neuroexcitatory effects of domoic acid. Fund Appl Toxicol 31: $162-168$.

8. Scholin CA, Gulland F, Doucette GJ, Benson S, Busman M, et al. (2000) Mortality of sea lions along the central California coast linked to a toxic diatom bloom. Nature 403: 80-84.

9. Bates SS, Trainer VL (2006) Diatoms. In: Graneli E, Turner JT, eds. Ecology of Harmful Algae. Heidelberg: Springer-Verlag. pp 81-93.

10. Pan Y, Bates SS, Cembella AD (1998) Environmental stress and domoic acid production by Pseudo-nitzschia: a physiological perspective. Nat Toxins 6: 127-135.

11. Bates SS, Garrison DL, Horner RA (1998) Bloom dynamics and physiology of domoic acid-producing Pseudo-nitzschia species. In: Anderson DM, Cembella AD, Hallegraeff GM, eds. Physiological Ecology of Harmful Algal Blooms. Heidelberg: Springer-Verlag. pp 267-292.

12. Lundholm N, Hansen PJ, Kotaki Y (2004) Effect of $\mathrm{pH}$ on growth and domoic acid production by potentially toxic diatoms of the genera Pseudo-nitzschia and Nitzschia. Mar Ecol Prog Ser 273: 1-15.

13. Trimborn S, Lundholm N, Thoms S, Richter KU, Krock B, et al. (2008) Inorganic carbon acquisition in potentially toxic and non-toxic diatoms: the effect of $\mathrm{pH}$-induced changes in seawater carbonate chemistry. Physiol Plant 133: 92-105.

14. Maldonado MT, Hughes MP, Rue EL, Wells ML (2002) The effect of Fe and $\mathrm{Cu}$ on growth and domoic acid production by Pseudo-nitzschia multiseries and Pseudo-nitzschia australis. Limnol Oceanogr 47: 515-526.

15. Wells ML, Trick CG, Cochlan WP, Hughes MP, Trainer VL (2005) Domoic acid: The synergy of iron, copper, and the toxicity of diatoms. Limnol Oceanogr 50(6): 1908-1917.

16. Armstrong-Howard MD, Cochlan WP, Ladizinsky N, Kudela RM (2007) Nitrogenous preference of toxigenic Pseudo-nitzschia australis (Bacillariophyceae) from field and laboratory experiments. Harmful Algae 6(2): 206-217.

17. Sun J, Hutchins DA, Feng Y, Seubert EL, Caron DA, et al. (2011) Effects of changing $\mathrm{pCO}_{2}$ and phosphate availability on domoic acid production and physiology of the marine harmful bloom diatom Pseudo-nitzschia multiseries. Limnol Oceanogr 56(3): 829-840. until analysis. Cellular biogenic silica (BSi) was measured according to Brzezinski and Nelson (1995) [42].

\section{Statistics}

Differences between treatments for all parameters were tested using two-way ANOVA and the individual treatments were compared using Tukey's Multiple Comparison Test or Student's ttest. All analyses were performed using SigmaPlot 10 software.

\section{Acknowledgments}

The authors would like to thank B. Jenkins and D. Chappelle for 18S-based molecular species identifications, S. Sanudo-Wilhelmy for analytical assistance and J. Sun for help with statistics.

\section{Author Contributions}

Conceived and designed the experiments: AOT DAH FF. Performed the experiments: AOT FF. Analyzed the data: AOT DAH FF. Contributed reagents/materials/analysis tools: AOT DAH FF. Wrote the paper: AOT DAH.

18. Schnetzer A, Miller P, Schaffner RA, Stauffer B, Jones B, et al. (2007) Blooms of Pseudo-nitzschia and domoic acid in the San Pedro Channel and Los Angeles harbor areas of the Southern California Bight, 2003-2004. Harmful Algae 6: 372-387.

19. Pan Y, Subba Rao DV, Mann KH, Brown RG, Pocklington R (1996b) Effects of silicate limitation on production of domoic acid, a neurotoxin, by the diatom Pseudo-nitzschia multiseries. I. Batch culture studies. Mar Ecol Prog Ser 131: 225-33.

20. Pan Y, Subba Rao DV, Mann KH, Li WKW, Harrison WG (1996c) Effects of silicate limitation on production of domoic acid, a neurotoxin, by the diatom Pseudo-nitzschia multiseries II. Continuous culture studies. Mar Ecol Prog Ser 131: 235-243.

21. Feely RA, Sabine CL, Hernandez-Ayon JM, Ianson D, Hales B (2008) Evidence for upwelling of corrosive "acidified" water onto the continental shelf. Science 320(5882): 1490-1492.

22. Hutchins DA, Bruland KW (1998) Iron-limited diatom growth and Si:N uptake ratios in a coastal upwelling regime. Nature 393: 561-564.

23. Milligan AJ, Varela D, Brzezinski MA, Morel FMM (2004) Dynamics of silicon metabolism and silicon isotopic discrimination in a marine diatom as a function of $\mathrm{pCO}_{2}$. Limnol Oceanogr 49(2): 322-329.

24. Firme GF, Rue EL, Weeks DA, Bruland KW, Hutchins DA (2003) Spatial and temporal variability in phytoplankton iron limitation along the California coast and consequences for $\mathrm{Si}, \mathrm{N}$, and $\mathrm{C}$ biogeochemistry. Global Biogeochem $\mathrm{Cy}$ 17(1): 1016 .

25. Wood ES, Benitez-Nelson C, Morton S, Anderson C, Burrell C, et al. (2011) Pseudo-nitzschia and domoic acid fluxes in Santa Barbara Basin (CA) from 1993 to 2008. Harmful Algae 10(6): 567-575.

26. Anderson CR, Brzezinski MA, Washburn L, Kudela RM (2006) Circulation and environmental conditions during a toxigenic Pseudo-nitzschia australis bloom in the Santa Barbara Channel, California. Mar Ecol Prog Ser 327: 119-133.

27. Lane JQ Raimondi PT, Kudela RM (2009) Development of a logistic regression model for the prediction of toxigenic Pseudo-nitzschia blooms in Monterey Bay, California. Mar Ecol Prog Ser 383: 37-51.

28. Anderson CR, Siegel DA, Kudela RM, Brzezinski MA (2009) Empirical models of toxigenic Pseudo-nitzschia blooms: potential use as a remote detection tool in the Santa Barbara Channel. Harmful Algae 8(3): 478-492.

29. Macintyre HL, Stutes AL, Smith WL, Dorsey CP, Abraham A, et al. (2011) Environmental correlates of community composition and toxicity during a bloom of Pseudo-nitzschia spp. in the northern Gulf of Mexico. J Plank Res 33(2): 273-295.

30. Ramsey UP, Douglas DJ, Walter JA, Wright JLC (1998) Biosynthesis of domoic acid by the diatom Pseudo-nitzschia multiseries. Nat Toxins 6(3-4): 137-146.

31. Trick CG, Bill BD, Cochlan WP, Wells ML, Trainer VL, et al. (2010) Iron enrichment stimulates toxic diatom production in high nitrate, low-chlorophyll areas. Proc Natl Acad Sci USA 107: 5887-5892.

32. Saito MA, Goepfert TJ, Ritt JT (2008) Some thoughts on the concept of colimitation: Three definitions and the importance of bioavailability. Limnol Oceanogr 53: 276-290.

33. Guillard RRL (1975) Culture of phytoplankton for feeding marine invertebrates. In Smith WL, Chanley MH, eds. Culture of Marine Invertebrate Animals. New York: Plenum Press. pp 26-60. 
34. Utermöhl H (1931) Neue Wege in der quantitativen Erfassung des Planktons. (Mit besonderer Beriicksichtigung des Ultraplanktons). Verh Int Verein Limnol 5: 567-596.

35. Guillard RRL (1973) Division Rates. In: Stein J, ed. Culture Methods and Growth Measurements. New York: Cambridge University Press. pp 289-312.

36. Mafra LL, Jr., Leger G, Bates SS, Quilliam MA (2009) Analysis of trace levels of domoic acid in seawater and plankton by liquid chromatography without derivatization, using UV or mass spectrometry detection. J Chromatogr A 1216(32): 6003-11.

37. Lewis E, Wallace DWR Program developed for $\mathrm{CO}_{2}$ system calculations, Carbon Dioxide Information Analysis Center, Report ORNL/CDIAC-105, Oak Ridge National Laboratory, Oak Ridge, Tennessee, USA.

38. Alley RB, Berntsen T, Bindoff, NL, Chen Z, Chidthiasong A, et al. (2007) Summary for policymakers. In: Solomon S, Qin D, Manning M, Chen Z,
Marquis M, et al. (2007) Climate change 2007: The physical science basis. Contribution of Working Group I to the fourth assessment report of the Intergovernmental Panel on Climate Change. New York: Cambridge University Press.

39. Welschmeyer NA (1994) Fluorometric analysis of chlorophyll a in the presence of chlorophyll b and phaeopigments. Limnol Oceanogr 39: 1985-1992.

40. Hutchins DA, DiTullio GR, Zhang Y, Bruland KW (1998) An iron limitation mosaic in the California coastal upwelling regime. Limnol Oceanogr 43: 1037-54.

41. Fu F, Warner ME, Zhang Y, Feng Y, Hutchins DA (2007) Effects of increased temperature and $\mathrm{CO}_{2}$ on photosynthesis, growth and elemental ratios of marine Synechococcus and Prochlorococcus (Cyanobacteria). J Phycol 43: 485-496.

42. Brzezinski MA, Nelson DM (1995) The annual silica cycle in the Sargasso Sea near Bermuda. Deep Sea Res 42: 1215-1237. 